\title{
Razão, cegueira e mito
}

\author{
Anderson Zalewski Vargas
}

\begin{abstract}
O mundo hobbesiano do Holocausto não veio à tona saindo de sua sepultura rasa demais, ressuscitado pelo tumulto das emoções irracionais. Apareceu (...) num veículo de produção industrial, empunhando a arma que só a ciência mais avançada poderia fornecer e seguindo um itinerário traçado por uma organização cientificamente administrada. A civilização moderna não foi a condição suficiente do Holocausto; foi, no entanto, com toda a certeza, sua condição necessária. Sem ela, Holocausto seria impensável. Foi o mundo racional da civilização moderna que tornou viável o Holocausto. ${ }^{1}$
\end{abstract}

O tema geral deste artigo é a dificuldade da "razão" sentir-se responsável e ser responsabilizada pelas suas realizações abomináveis, como se não estivesse sujeita às limitações da condição humana, como se garantisse a seus saberes o privilégio de conhecer o(s) significado(s) último(s) do que revelam, do que propugnam, e conhecessem o segredo do controle garantidor das implicações de ambos. ${ }^{2}$

Por "razão", refiro-me a uma concepção genérica capaz de reunir em si todos os saberes científicos, acadêmicos, "sistemáticos", que nós, profissionais dessas áreas, podemos usar em situações de autoavaliação conjunta, especialmente quando nos contrapomos a saberes outros, comuns, estranhos ou primeiros. Mais especificamente, quando consideramos ser o "orgulho de Platão, Descartes e Kant" e pensamos estar em melhores condições de pensar e agir do que nossos antepassados e muitos de nossos contemporâneos - uma perspectiva da "razão nobre" e também do senso comum. ${ }^{3}$ Corresponde ao uso espontâneo da noção, difícil de ser precisada em todos seus aspectos, mas cujo caráter deverá ficar claro ao leitor ao final deste texto.

Este trabalho é resultado de uma pesquisa formalmente encerrada, cujo objetivo principal foi avaliar as implicações para a história do abandono da noção de mito, tal como defendido por Marcel Detienne e Claude Calame. ${ }^{4}$ Carlo Ginzburg, em texto intitulado "Mito, distância e mentira", mencionou, en passant, essas proposições condenatórias daquela categoria e da disciplina dedicada ao seu estudo, a mitologia. ${ }^{5} \mathrm{O}$ aspecto positivo por ele considerado - a atenção despertada para a ideia de mito como mentira, elemento da variegada crítica platônica do mythos - é o ponto de partida de seu argumento sobre a relação entre dominação política e o que define, ao final, como "um conto que já foi contado, um conto que já se conhece". ${ }^{6}$ Observa, contudo, ser "mais que discutível" a conclusão de que inexista uma narrativa universal designável por mito e que a ciência deste seja um "discurso agressivo feito em nome da razão contra um saber tradicional indeterminado". ?

"Desde que se abandonam as categorias a priori para interrogar os textos mais de perto, a fronteira entre mito e História deixa de oscilar a ponto de parecer impossível decidir”, escreveu, em 1996, JeanPierre Vernant. ${ }^{8}$ Muito antes dessa constatação, o filósofo inglês Francis Cornford fizera de sua carreira uma singular empreitada ao defender a continuidade entre mito e razão. Quando a maioria dos helenistas defendia a tese do surgimento do pensamento racional como ruptura para com o mitológico, graças à genialidade da "raça" helênica, ele propusera a continuidade tanto no âmbito histórico - em obra consagrada a Tucídides - quanto no filosófico. ${ }^{9}$ A partir de meados dos anos 1950, a consciência das mazelas do evolucionismo e do etnocentrismo ocidentais estimulou empreendimentos intelectuais como o estruturalismo de Claude Lévi-Strauss, o qual defendeu certa equivalência dos modos de pensamento racional e mítico. ${ }^{10}$ Ainda na antropologia, Jack Goody procurou eliminar o obstáculo evolucionista através da tese da relação entre modos de pensamento e modos de comunicação. Não seria o "gênio de uma raça", mas o meio de comunicação, oral ou escrito, o gerador de modalidades diversas do pensar humano. ${ }^{11}$ 
Nesse contínuo repensar constituidor da mitologia, Marcel Detienne e Claude Calame distinguem-se pela radicalidade de suas críticas e propostas. ${ }^{12} \mathrm{O}$ que ambos fizeram fora, em parte, realizado pelo próprio Vernant em texto de 1974, Razôes do mito. A busca por procedimentos de interpretação e de técnicas de decifração do que poderia parecer, em princípio, uma "penca de fábulas absurdas" o levara a reconstituir a história de transformação de mito, de "discurso", "fala", ${ }^{13}$ em história estranha, absurda, e oposta às compreensões racionais do mundo. ${ }^{14} \mathrm{O}$ mesmo movimento analítico o levara a reavaliar as modernas proposiçóes de enfrentamento do que fora definido, no nascer da etnografia e da antropologia, como as paradoxais e chocantes histórias e pensamentos dos modernos bárbaros: os habitantes primeiros das Américas, Ásia e África. Quando Detienne e Calame reeditaram tais procedimentos de análise, de forma mais meticulosa e abrangente, fizeram-no a partir de outra perspectiva: a moderna ciência dos mitos tornou-se, antes de tudo, um revelador documento - muitas vezes constrangedor - para a compreensão de singulares “indígenas" ${ }^{15}$ Foram destacados o aspecto segregacionista da "razão helênica"; a distinção entre as concepções antigas e modernas de mito; e o caráter etnocêntrico de toda a mitologia até então desenvolvida. O estruturalismo de Claude Lévi-Strauss, alternativa de estudo privilegiada por Vernant nos anos $70,{ }^{16}$ tornou-se capítulo de um equivocado e embaraçoso empreendimento intelectual: mito passou a ser um objeto ilusório, ${ }^{17}$ a mitologia, um segregacionista discurso identitário. Ao final, restava, de acordo com os dois críticos, duvidar da própria existência de mythos como categoria universal de narrativa e pensamento, bem como reiniciar o estudo daquilo do que fora até então definido como mitológico. ${ }^{18}$

A contínua produção acadêmica sobre mito e mitologia - nas áreas dos Estudos Antigos, da História das Religióes, da Antropologia -, a ubiquidade de "mito" na linguagem cotidiana, demonstram a vitalidade daquelas palavras que sobreviveram incólumes às críticas de Detienne e Calame. ${ }^{19}$ É possível, ainda, que uma reformulação de sentido permita a superação dos impedimentos apontados pelos dois críticos, como argumenta Ordep Serra: ${ }^{20}$ mito pode adquirir um referente concreto aceitável, se despojado de seus negativos aspectos etnocêntricos, e pode ser usado de tal forma que não seja um obstáculo intransponível à compreensão de sociedades "exóticas". ${ }^{21}$ Será preciso, entretanto, uma transformação substancial para que sua simples menção não invoque, explícita ou implicitamente, noções ainda correlatas de "primitivo", "irracional”, "bárbaro”; será necessária uma mudança considerável para que mito não sirva como meio de instauração de distâncias equivocadas entre sociedades e saberes.

No caso da disciplina histórica, mito é uma categoria secundária, quase restrita aos universos da História Antiga e Medieval. Torna-se, porém, valiosa quando os historiadores empenham-se em afirmar a peculiar natureza superior de seu conhecimento, ou quando criticam o que entendem ser as mazelas de seu e de outros tempos. Outros domínios do saber racional podem também recorrer ao "argumento mitológico" para eximirem-se de erros e responsabilidades constrangedoras. Nesses casos, a análise do uso daquela desprestigiada ideia revela uma antiga ilusão característica da cegueira da razão: a de que o pensamento intelectual, pelo seu inerente caráter, é garantia de superação das limitações impostas pela condição humana a outros saberes. Esse e outros desvarios da razão cega, e o papel da ideia de mito na sua sustentação, são os temas deste artigo.

\section{Reflexão e isolamento}

Tendo por alvo o que diz ser o "mito de Protágoras"22 - a tese que identifica sensação (aisthésis) e conhecimento (episteme) -, o Sócrates do diálogo platônico Teeteto convida seu interlocutor, Teodoro, a examinar os "diretores do coro", visando demonstrar as diferenças entre estes, os filósofos, que sabem e o vulgo, ignorante:

De início, devemos observar acerca dos primeiros [os "diretores"] que desde a mocidade o que mais do que tudo ignoram é o caminho da ágora ou onde fica o tribunal, a sala do conselho e qualquer outro local 
de reunião pública; não ouvem nem vêem as leis nem as decisões escritas ou faladas. As disputas dos cargos públicos nas hetérias, as reuniões e os festins, os banquetes animados por tocadoras de flautas: nem em sonhos lhes ocorre comparecer a nada disso. Nasceu na cidade alguém de nobre ou baixa estirpe? Certo cidadão herdou tara de seus antepassados, homens ou mulheres? É que o filósofo conhece tão pouco, como se diz, como quanta areia há no mar. Nem chega mesmo a saber que não sabe nada disso. ${ }^{23}$

No contexto da pólis, essa descrição é a de um ser alienado por completo da vida comum. Nas dimensões restritas da $a s t u{ }^{24}$ o filósofo ignorava a ágora - o espaço por excelência do contato diário dos habitantes e visitantes das póleis -, assim como desconhecia os locais em que os cidadãos exerciam seus direitos e cumpriam suas obrigações. Seu êthos, seu modo de ser, tornava impensável participar dos banquetes, fosse para se divertir, fosse para participar das maquinações políticas que também podiam ocorrer em reuniōes festivas. Sábio, desde jovem, revelava sua absoluta indiferença para com a vida comum na própria ignorância de sua condição de "alienado".

$\mathrm{Na}$ imediata sequência do diálogo, Sócrates esclarece: esse jeito de ser decorria da modalidade particular do pensamento caracterizador do sábio, que o levava a se ausentar completamente da pólis:

Porém não se alheia dessas coisas por vanglória, mas porque realmente só de corpo está presente na cidade em que habita, enquanto o pensamento (dianoia ${ }^{25}$ ), considerando inane e sem valor todas as coisas merecedoras apenas de desdém, paira acima de tudo, como diz Píndaro, sondando os abismos da terra e medindo a sua superfície, contemplando os astros para além do céu, a perscrutar a natureza em geral e cada ser em sua totalidade, sem jamais descer a ocupar-se com o que se passa a seu lado. ${ }^{26}$

Nessa passagem em particular, Platão é radical na caracterização dos “dois mundos" e da dedicação do pensamento filosófico ao mundo supra-sensível. ${ }^{27}$ Em razão dessa separação, argumentou na sequência, não deveria surpreender a curiosa inabilidade dos "diretores do coro" com aspectos da vida cotidiana. ${ }^{28}$ O exemplo apresentado é a conhecida história de Tales que, ocupado com as coisas do céu, teria caído em um poço, sofrendo por isso a zombaria de uma moça trácia. Platão observou: a inabilidade para as coisas práticas fazia do filósofo um imbecil aos olhos de todas as pessoas. ${ }^{29}$

A nossos olhos, tudo isso pode parecer antiga manifestação de delírio intelectual, mas Hannah Arendt ponderou serem humanamente compreensíveis essas concepçóes filosóficas. ${ }^{30} \mathrm{O}$ "especular de maneira significativa sobre o desconhecido e o incognoscível" imporia ao indivíduo o alheamento em relação às pessoas e aos fatos da vida comum. Essa forma de pensamento seria de tal modo absorvente que impediria a realização de qualquer outra atividade simultânea: o solitário isolamento seria a condição inevitável daquele que é dominado pelo diálogo sem som de si consigo mesmo. ${ }^{31}$ Da experiência do pensamento decorreria a proverbial distração do pensador de todos os tempos, sujeito a prosaicos acidentes cotidianos quando imerso em sua reflexão ensimesmada.

Ressentidos, no entanto, com o riso do vulgo, argumentou Arendt, muitos pensadores teriam se refugiado na consoladora ideia de pertencerem a um mundo distinto, superior ao universo dos comuns mortais. Esse consolo diminuiria seu próprio desconforto com a singular experiência do pensar. Pertencendo de forma indissolúvel à comunidade humana, no entanto, o próprio intelectual desconfiaria da atividade reflexiva e combateria esse mal-estar de variadas formas: no Mundo Antigo, exaltando a morte por livrá-lo dos óbices colocados ao pensamento pela dor e pelo prazer ${ }^{32}$ ou afirmando a hostilidade da multidão que, para Arendt, em geral, teria sido apenas indiferente ou, quando muito, jocosa para com os filósofos. ${ }^{33}$

$\mathrm{O}$ intelectual antigo também poderia reagir a esse mal-estar atuando. O próprio Platão, em sua Sétima Carta, diz ter se lançado à aventura em Siracusa movido pela vergonha de sentir-se como um homem incapaz de agir de acordo com suas ideias. ${ }^{34}$ Nas leis, argumentou por sua vez Aristóteles, estava a salvação das póleis, o que obrigava o orador a conhecer a legislação da cidade para poder ser persuasivo nas assembleias. ${ }^{35} \mathrm{O}$ mesmo filósofo também ponderou que, em questôes disputadas, era por vezes maior bem aquilo de que todos participavam, porque não era honorável a indiferença às coi- 
sas comuns. ${ }^{36}$ A dedicação exclusiva aos estudos, por outro lado, levou Cícero a advertir seus leitores a não crerem no vaticínio platônico sobre os filósofos: "alegando dedicarem-se à busca da verdade e desprezarem aquilo que a maioria dos homens procura apaixonadamente, chegando a lutar entre si para alcançá-lo, só por causa disso são justos!"37

A interpretação de Arendt não exclui outras razões da divisão dos mundos, como as relacionadas a estratégias de poder e identidade. Ela me parece interessante, todavia, por relacionar aquela tradicional concepção à experiência real implicada pela reflexão. ${ }^{38}$ É importante também por destacar que a sensação de "alheamento" não implica um real rompimento com o mundo, nem a existência de uma dimensão que não seja a das aparências. À sensação não corresponde uma ruptura com o mundo cotidiano; os intelectuais permanecem nele mergulhados e, uma vez terminado tal gênero de reflexão, voltam a viver como qualquer outro indivíduo. O isolamento - e não a ruptura - perduraria pelo tempo da reflexão, necessariamente limitado. Uma consequência importante desse argumento é a valorização da vida ordinária: ponderou Arendt que a origem das questôes filosóficas, mesmo das metafísicas, seriam experiências cotidianas porque a "necessidade da razão", isto é, "a busca de significado que faz com que os homens formulem questôes" não diferiria "em nada da necessidade que os homens têm de contar a história de algum acontecimento de que foram testemunhas, ou de escrever poemas a respeito dele". ${ }^{39} \mathrm{O}$ mundo, a despeito da sensação do filósofo, estaria inextricavelmente ligado ao pensamento intelectual. Uma vez interrompido este, o sábio voltaria a estar disponível para o mundo, do qual nunca se ausentara. Clifford Geertz, em sua Interpretação das culturas, objetou que mesmo um homem religioso age conforme outras regras quando não está no exercício de sua religiosidade. ${ }^{40}$ Creio que todos sentimos a multiplicidade de códigos que regem as diferentes partes de nossas vidas: como observou Paul Veyne, apenas em estados neuróticos essa multiplicidade é sentida como indício de hipocrisia. ${ }^{41}$

A sensação de afastamento da realidade pode, entretanto, levar o intelectual a se considerar estranho ao mundo, aos elementos da vida mundana. Em determinados casos, podemos nos considerar incapazes de cometer os erros daqueles que parecem ser prisioneiros do mundo das aparências. Quando isso ocorre, podemos recorrer à antítese mito-razão ou razão-desrazão com muita facilidade. Isso me parece evidente, quando o historiador enfrenta o tema da relação entre poder e identidade coletiva, ou reflete sobre as eventuais peculiaridades de seu pensamento.

\section{O erro dos outros}

"O próprio Estado não conhece leis não escritas mais poderosas do que o fundamento mítico", escreveu Nietzsche. Como vimos, de Platão em diante, essa ideia foi invocada em benefício de um bem comum identificado ora com uma ordem social a ser fundada, ora com a ordem social inexistente. Porém o uso do mito como mentira esconde algo mais profundo. A legitimação do poder remete necessariamente a uma história exemplar, a um princípio, a um mito fundador. Isso se torna evidente quando rebenta uma guerra civil: a legitimidade, em vez de ser tomada por um dado natural, torna-se para cada um objeto de escolha, tácita quem sabe. É um caso limite que ilustra um fenômeno mais geral: se os fundamentos do poder não são submetidos ao escrutínio da razão, a referência a eles se torna deferência exterior, jaculatória, rotina. Mas sempre, inevitavelmente, se volta para o mito fundador. ${ }^{42}$

Nessa citação, mito é um gênero particular de história: "exemplar" e "mentirosa”, mas capaz de gerar estabilidade ao ser aceita como "princípio" fundante de uma ordem social - seria a mais poderosa "lei não escrita" de um Estado. O poder em geral, o Estado em particular, teria nesse recurso sua mais poderosa arma para obtenção de legitimidade. Mais que um recurso eventual para situações de crise, seria uma necessidade. Ao "mito fundador" voltaria inevitavelmente, mesmo depois do seu desmascaramento pelo "exame racional", o único instrumento capaz de impedir que as referências aos fundamentos do poder sejam discursos quase religiosos: rotineiros e laudatórios ao tratarem de realidades superiores.

Difícil discordar desse argumento depois de tudo o que já foi feito, e continua sendo feito, em nome da nação, do Estado, do poder, da "ordem" em geral. Basta lembrar-se de como os europeus lança- 
ram-se à guerra, em 1914, movidos pelas altissonantes ideias de nação, pátria, deus e família; ou observar a reiteração norte-americana dos ideais de sacrifício nacional depois da declaração de "guerra contra o terror". ${ }^{43}$ Por outro lado, no mês de setembro, quando escrevo este texto, inicia-se a demonstração "cívica" do "gauchismo", espetáculo baseado em versão extremada das ideias historicamente equivocadas que tornam os habitantes do estado do Rio Grande do Sul, acadêmicos ou não, membros de uma orgulhosa comunidade particular. São Paulo, da mesma forma, faz da comemoração de seu levante contra o poder central um dos elementos de sua autocompreensão. Em termos nacionais, no ano de 2008, o centenário da chegada de D. João VI à sua colônia americana foi o mote para reflexôes, comemorativas ou não, de populares e acadêmicos sobre o surgimento de sua nação.

Talvez a visão estigmatizadora dos fundamentos da ordem nos impeça de compreender por que a identidade coletiva - nacional, regional, de grupos - necessita de narrativas que nos parecem ridículas e mentirosas e por que estas logram obter tamanha adesão. Por que a "ordem" reitera seu "mito fundador", mesmo depois de seu desmascaramento? Por que acreditamos novamente? A resposta apresentada por Ginzburg não é sui generis: a ausência de "razão" é que torna a maioria das pessoas vítimas das enganadoras histórias constituidoras de identidade social. O que é, contudo, esse elemento racional e quais são seus instrumentos que individualizam seu possuidor a ponto de ele poder desmascarar o poder, separando seu denunciante da multidão irracional?

Em conferência proferida em 1998, Eric Hobsbawm preocupou-se em advertir sua audiência universitária da tarefa do historiador em uma conjuntura de efervescência nacionalista:

História não é memória ancestral ou tradição coletiva. É o que as pessoas aprenderam de padres, professores, autores de livros de história e compiladores de artigos para revistas e programas de televisão. É muito importante que os historiadores se lembrem de sua responsabilidade, que é, acima de tudo, a de se isentar das paixóes de identidade politica - mesmo se também as sentirmos. Afinal de contas, também somos seres humanos. ${ }^{44}$

É um lugar-comum supor que o exercício da razão implica o domínio das paixões. ${ }^{45}$ De acordo com Hobsbawm, o historiador é um indivíduo que, a despeito de sua razão particular, é sujeito às paixões humanas ligadas às identidades políticas. É preciso intervir na vontade - sustentada por exercícios ascéticos? - para torná-lo imune à influência do desvario mundano; com isso, ele obtém a situação anímica capaz de torná-lo verdadeiro historiador, solitário certamente, mas imune e infenso ao perigoso arrebatamento coletivo capaz de causar desastres como o das lutas entre sérvios e croatas. Em seu estudo sobre o nacionalismo, Hobsbawm já escrevera que os historiadores "estão profissionalmente obrigados a não compreender a história de modo errado, ou ao menos fazer um esforço". ${ }^{46}$ Ser "orgulhosamente católico irlandês ou protestante-do-Ulster irlandês" não seria incompatível com o estudo da história irlandesa; ser ativista feniano, porém, seria um óbice considerável, assim como seria incompatível escrever "uma história genuinamente séria dos judeus" e militar no sionismo. Para esses, a única alternativa seria o abandono de suas convicções, à entrada das bibliotecas e arquivos. Muitos "historiadores nacionalistas", complementou o intelectual inglês, foram incapazes de fazê-lo; quanto a ele, confessa: "felizmente não precisei deixar minhas convicções não históricas de lado". ${ }^{47}$

Entretanto, se até o momento a tese da transmissão genética de conceitos resta improvável, e podemos pensar que somos resultado do que podemos dizer genericamente "cultura", o elo identitário nacional pode não ser uma completa mazela, e sim uma das diversas alternativas humanas de vida em comum. Como qualquer outra, implica riscos; mas religiāo, família, regionalismo, ideologias intelectuais..., qualquer espécie de formação e orientação dos indivíduos contém alternativas ou implica consequências sombrias. O problema é pensar que uma forma específica pode escapar a essa condição ou que possamos viver sem alguma "identidade fabricada" ou não entender porque gostamos de nos sentir membros de algum grupo ou comunidade. ${ }^{48}$

Jean-Pierre Vernant, na revisão de sua carreira, reafirmou a historicidade da razão, ${ }^{49}$ sua multiplicidade,${ }^{50}$ e fez interessantes consideraçôes sobre racionalidade e irracionalidade: 
A racionalidade não está dada antes da ciência para conduzir e fixar seu movimento de fora. Ela é imanente ao movimento das diversas disciplinas científicas: ela se fabrica dentro e por suas iniciativas, no contato com seus "reais" e nas resistências destes reais. Quanto à irracionalidade, é outro problema. Uma vez que suas raízes são sociais e psicológicas, as formas que adota, os setores em que se manifesta e que investe, mesmo nos casos em que parecem se aproximar da ciência, como a astrologia ou a comunicação de pensamento, são profundamente estranhos aos debates da pesquisa que se faz e a suas apostas do ponto de vista da racionalidade. Constatação reconfortante na medida em que implica que entre racionalidade e irracionalidade a fronteira não é tão flutuante quanto alguns gostariam que se acreditasse, mas é também desabusada porque nos inclina a pensar que a extensão da pesquisa em todos os campos, os progressos da ciência, por mais espetaculares que sejam, são impotentes para suprimir, em uma civilização, as irrupções e até as penetrações avassaladoras do irracional. ${ }^{51}$

Nos termos desse depoimento, o universo racional resulta restrito em dois sentidos: em primeiro lugar, como produto exclusivo de específica atividade, a intelectual; segundo, como configurador de domínio resumido à prática daquela atividade de pensamento. A razão é imanente ao seu exercício e separada das demais esferas da ação humana. Avulta, em contraste, a caracterização da irracionalidade. Ela é um "problema" completamente "outro". É distinto e separado da razão pelas suas origens, as quais são "sociais e psicológicas". Não se trata de produto pensado ou indesejado de determinado pensar humano. Seu surgimento é ligado ao todo social e à parcela específica deste: a psique. Em seguida, a particularização distintiva é acentuada pela afirmação da completa alteridade, em contraponto à razão, das "formas" e dos "setores" de "manifestação" e de "investimento" da irracionalidade. Não há como confundir razão e desrazão: distinguem-se pela forma, pelos seus ambientes e campos de atuação.

Dessa caracterização, Vernant desloca seu raciocínio para a perspectiva valorativa das diferenças, sendo sua conclusão paradoxal porque não há motivo para nos preocuparmos quando pensamos e produzimos no âmbito de nossa prática intelectual: permanecemos sempre no universo racional positivo. As fronteiras, afirma, não são, como pensamos muitas vezes, "flutuantes", mas fixas e, sob certo ângulo, tranquilizadoras. O que tranquiliza, no entanto, é também motivo de perturbação, porque as iniciativas racionais permanecem condenadas aos seus restritos domínios. Seu negativo, a irracionalidade, cuja origem é social (e não intelectual), e domínio, amplo, é ameaça externa e perene pronta para, em situações adequadas, "irromper" e "penetrar" avassaladoramente na "civilização". Estaríamos forçados, pois, a permanecer em alerta permanente contra as invasóes desse inimigo estrangeiro ao universo racional. ${ }^{52}$

Concebendo-se como ser dotado de uma inteligência restrita ao seu domínio de ação ou à sua condição anímica superior, o intelectual pode ser levado a sentir-se superior aos demais seres humanos, capaz de resistir às paixões da coletividade e de denunciar as manobras nelas baseadas. A contrapartida disso pode ser a sensação de isolamento da maioria sujeita à irracionalidade. Sendo assim, não há como o erro abominável ser explicado pela ação e pelas ideias do pensador, filósofo, historiador. Há, portanto, graves implicações dessa complacente e orgulhosa autoconcepção, como a cegueira para com a virtualidade terrífica de todo pensamento e ação humanos. ${ }^{53}$

\section{A razão e o abominável: o caso do Holocausto}

Em "A pólis e a criação da democracia", o filósofo Cornelius Castoriadis manifestou sua absoluta discordância com a ideia de que as diferenças entre "os gregos, os nhambiquaras e os bamileques" são "puramente descritivas". ${ }^{54}$ Não que haja alguma distinção de "valor humano", "mérito" ou "dignidade", mas seria um erro considerar, como teria feito Claude Lévi-Strauss, o psicanalista como uma "variante ocidental do xamã" e os etnólogos, como uma "variedade local de feiticeiros". ${ }^{55}$ Apenas, na tradição inaugurada pelos gregos, teria havido o rompimento da "clausura" que impedira as sociedades anteriores, e muitas das posteriores, de ter um real interesse pelos outros. Em decorrência desse rompimento, os gregos teriam sido obrigados a se interrogar arrazoadamente sobre o que seria bom e mau, "sobre os 
próprios princípios, em virtude dos quais podemos afirmar, superando as trivialidades e preconceitos tradicionais, que uma coisa é boa ou má, porque nasceu na Grécia”. ${ }^{56}$

Essa compreensão do significado da tradição inaugurada pelos helenos não cegou Castoriadis de forma a impedi-lo de concluir que, a despeito de suas qualidades, ela não oferecia "repouso":

Pois, embora ela tenha engendrado a democracia e a filosofia, as revoluçôes americana e francesa, a Comuna de Paris e os conselhos operários húngaros, o Partenão e Macbeth, ela também produziu o massacre dos mélios pelos atenienses, a Inquisição, Auschwitz, o Gulag e a bomba H. Criou a razão, a liberdade e a beleza - mas também a monstruosidade em massa. Nenhuma espécie animal poderia ter criado Auschwitz ou o Gulag: para mostrar-se capaz disso é preciso ser humano. E essas possibilidades extremas da humanidade no domínio do monstruoso concretizaram-se, par excellence, em nossa tradição. ${ }^{57}$

Escreveu Sófocles, em sua Antígona (332-375), ser o homem deinóteron: o que há de mais temível dentre as coisas terrificantes... capaz de subjugar terra, mar, seres... criar e transmitir pensamentos, palavras, leis... curar doenças, defender-se do frio e do calor... mas cujo engenho ora o leva para o bem, ora o leva para o mal, "para além do que se espera". ${ }^{58} \mathrm{O}$ homem ocidental foi quem, como escreveu Castoriadis, concretizou a ambígua essência humana, conjugadora do admirável e do monstruoso. A literatura sobre o Holocausto, entretanto, demonstra a dificuldade da "razão", do homem afinal, reconhecer-se como responsável pelos atos mais terríficos, vendo neles o resultado de suas faculdades assombrosas. Exemplo admirável desta concepção é a obra do geneticista alemão Benno Müller-Hill, cujo título, Ciência assassina, indica o objetivo de fazer do saber científico o ator responsável pelo moderno genocídio. No prefácio à edição brasileira, o psicanalista Chaim Samuel Katz observa quanto a esta pretensão:

Para os que se habituaram a pensar numa "imortalidade da ciência", na postulação de que tudo o que vem das ciências traz a característica de verdade permanente, surpreende um título onde se indica que a ciência mata. Mais ainda: que certos assassinatos só se tornam possíveis com a intervenção dos cientistas. ${ }^{59}$

Sobressaltados devem ficar os leitores com a incisiva e crua argumentação de Katz. A ciência mata porque seus parâmetros epistemológicos não são isolados do mundo, nem tampouco neutros, inocentes, benfazejos em si. Antiplatonicamente, Katz afirma: os cientistas fazem parte do mundo, mesmo quando estão em seus laboratórios elaborando seu conhecimento; não há um abismo entre os mundos das vidas prática e teórica. E mais: para além da satisfação decorrente da produção do conhecimento, a ciência proporciona prazer pelo apossamento dos outros, algo escamoteado pela sua seriedade manifesta. ${ }^{60}$ Por isso, Chaim Katz emprega os verbos "matar" e "tornar" no presente: a ciência "mata", e certos assassinatos "se tornam possíveis" pela intervenção de cientistas. O saber por excelência seria essencialmente violento; e na Alemanha, entre 1933 e 1945, teria havido a sinistra convergência de duas "brutalidades": a nazista $e$ a científica. ${ }^{61}$

Por ser "brutal", sujeitar terceiros, escreve Katz, Müller-Hill não deveria se surpreender com a negativa de alguns cientistas sobreviventes - ou de seus auxiliares e parentes - em tratar do assunto; ou com a afirmação de desconhecimento, por parte de seus perpetradores, das esterilizações, da segregação, da eutanásia, do extermínio. Tudo ocorreu porque contou com o apoio e consentimento científico. Foi normal... E cientistas podem novamente propor e se envolver em atividades similares, desde que "possam ser reconhecidos e não sejam criticados pelo grupo ao qual pertencem". ${ }^{62}$

Concordar com Chaim Katz exige radical reformulação das nossas ideias sobre ciência e, por conseguinte, sobre a "razão". A dificuldade desta tarefa é revelada em importantes estudos sobre a eugenia e o extermínio, na forma de juízos que isentam a ciência, na ambiguidade e contradição de argumentos e avaliações. Um desses juízos inocentadores é o que classifica a ciência daqueles tempos como falsa: "mesmo hoje, preferimos perceber a era nazista como um período de 'pseudociência”, escreveu Katrin Weigmann. ${ }^{63} \mathrm{O}$ extermínio, escreveu Edwin Black em seu alentado trabalho sobre a eugenia norte-americana, foi "verdade científica", não restrita aos limites do Estado nazista e da academia alemã: nas primeiras 
seis décadas do século XX, foi tese que granjeou status científico, graças ao trabalho de "respeitados professores" de "universidades de elite" norte-americanas, e que contou com ricos patronos como a Carnegie Institution ${ }^{64}$ e a Fundação Rockefeller, que apoiou cientistas do Instituto Kaiser Guilherme até depois do início da guerra. ${ }^{65} \mathrm{~A}$ eugenia em si nasceu na Inglaterra - com o contador Francis J. Galton (18221911) - e progrediu admiravelmente nos Estados Unidos com o trabalho e o ativismo do zoólogo Charles Davenport (1866-1944) ${ }^{66}$ que teve grande receptividade na Alemanha do entre-guerras. ${ }^{67}$ A despeito dessas palavras, e de parte considerável de seu trabalho, Black também considera o movimento racista como "pseudocientífico", como uma "fraude acadêmica". Da mesma forma, a brasileira Pietra Diwan, em breve história sobre a eugenia no Brasil e no mundo, qualifica aquela como uma "pseudociência". ${ }^{68}$ Porém,

isto é perigoso, pois é como se eximisse cientistas de qualquer responsabilidade pelos crimes cometidos. "Atos criminosos deste tipo são uma vergonha indesculpável, não apenas para os que os organizaram, mas também para aqueles que os toleraram, de fato, para as próprias ciências da vida, em nome das quais foram cometidos", Markl disse em seu discurso. ${ }^{69}$ "[Mengele] correspondeu-se com eles [cientistas do Instituto Kaiser Guilherme] na linguagem da medicina, e esta linguagem exige precisão e realismo", diz Jona Laks, responsável pela "Organização Gêmeos Mengele", e ela própria vítima de Mengele. ${ }^{70}$

A dificuldade de aceitar a responsabilidade racional pelas abjeções do início do século XX, a cegueira característica do pensamento intelectual, apresenta caráter peculiar no trabalho de Müller-Hill. Ao longo das páginas do seu pequeno livro, abundam dados sobre o pensamento eugênico alemão, a relação deste com o trabalho de psiquiatras, antropólogos e médicos de diversas especialidades, a ligação de todos com respeitáveis instituições científicas como o Instituto Kaiser Guilherme de Antropologia, Ciência da Hereditariedade Humana e Eugenia. Na seção "Uma crônica alemã", podemos acompanhar um arrolamento cronológico constrangedor que se inicia em $1900 \mathrm{com}$ a informação de que a redescoberta dos trabalhos de Gregor Johann Mendel (1822-84) - dedicados exclusivamente à hereditariedade de caracteres de espécimes vegetais, como a ervilha - foi interpretada como confirmação científica da tese de que as qualidades humanas eram "principalmente hereditárias". O autor informa a fundação, em 1905, da "Sociedade para a Higiene Racial” pelos médicos Alfred Ploetz (1860-1940) e Ernest Rüdin (1875-1952). O primeiro, que publicara em 1895 sua teoria da higiene racial, recebeu o título de doutor honorário da Universidade de Munique, em 1930; foi indicado para o Prêmio Nobel pela sua pesquisa sobre o impacto genético das guerras em 1936; e ingressou no Partido Nazista no ano seguinte. $\mathrm{O}$ segundo, seu cunhado, tomou parte ativa na política de extermínio nazista, juntamente com seus colegas Eugen Fischer, Fritz Lens, Otmar von Verschuer... A lista é imensa e envolve intelectuais de outras áreas: em 1920, destaca Müller-Hill, o "jurista prof. Binding” e o "psiquiatra Hoche" publicaram "A permissão para o extermínio de vidas indignas de viver" ${ }^{71} \mathrm{~A}$ ascensão de Hitler ao poder, comenta posteriormente, permitiu a adoção de políticas há muito propostas pelos defensores da melhora e preservação da raça ariana: "psiquiatras e antropólogos ficaram entusiasmados, pois viram nele o realizador de suas ideias". ${ }^{72}$ Anteriormente, contudo, o autor escrevera:

Quase todos os cidadãos lucraram com as medidas anti-semitas. (...) As vagas dos assistentes e professores perseguidos abriam possibilidades de carreira a estudantes e assistentes que, antes, não teriam a menor chance. Antropólogos e psiquiatras, em especial, almejavam o gigantesco fomento de suas pesquisas e se serviram da cientificação do mito nacional-socialista. Esse mito da "morte necessária" daqueles que pensavam diferente só precisou no início - por razões de propaganda - da aura científica, mas depois precisou de progressos técnicos. ${ }^{73}$

Os relatos sobre o Holocausto estão cheios de exemplos de "exploração de oportunidades" criadas naqueles tempos: poloneses ocupando casas de judeus deportados, judeus enriquecendo com os negócios dos guetos... ${ }^{74}$ Aos acadêmicos, e ao leitor comum, pode perturbar saber que cientistas e humanistas, assim como seus alunos, também aproveitaram as ocasiões criadas pelo novo regime, tais como oferta de financiamento, ou ocupação das vagas daqueles que foram excluídos do universo acadêmico e 
da vida comum. A expressão "cientificação do mito nacional-socialista" da "morte necessária", portanto, deveria despertar a atenção do leitor. Em primeiro lugar porque, como demonstra a própria "Crônica alemã” de Müller-Hill, a eugenia germânica é anterior ao nazismo. Em segundo lugar, porque - se estiver certo Edwin Black - no âmbito da eugenia norte-americana e internacional, o assassinato sempre foi uma opção, mesmo que alguns de seus propugnadores tenham se "limitado" à "eugenia positiva", prescritora, entre outras medidas, da esterilização, da proibição da imigração, do degredo daqueles que eram julgados ameaça à pureza das "raças superiores": doentes, judeus, italianos, eslavos, negros, "lixo branco", pobres em geral. ${ }^{75}$ A tese da "morte necessária" não foi, pois, invenção nazista. Por fim, a qualificação da ideia da "morte necessária" como "mito" capaz de conferir uma "aura científica" exime a "razão" da sua responsabilidade por aquela terrível tese e suas terríficas consequências. Aceitando-a, é no antitético universo do mito, falso e enganador, que procuraremos as razões da perseguição e extermínio dos "seres indignos de viver". A "cientificação" do "mito" teria servido apenas para fins de propaganda e, depois, a técnica teria operacionalizado os planos de extermínio. A ciência é, no conjunto do raciocínio, duplamente isentada.

Sempre poderemos, do nosso ponto de vista e da noção teórica de saber racional, concluir pelo caráter "pseudocientífico" da eugenia. Principalmente se acreditarmos que ciência e razão são neutras e essencialmente positivas. Restará, então, procurar explicações no âmbito do erro, da falha intelectual, da patologia das mentes e dos tempos. Müller-Hill, quando indaga sobre o que "fazia com que os médicos, em especial, se tornassem mensageiros do extermínio", argumenta que a tese médica da hereditariedade das doenças mentais não teria passado de um "equívoco" decorrente da confusão da medicina com o "sacerdócio", ocorrida muito tempo antes do nacional-socialismo:

Os professores de antropologia e de psiquiatria não acreditavam, assim como muitos teólogos, na exegese textual dos escritos produzidos por Hitler e seu discípulo Rosenberg. Até puderam afirmar que jamais haviam lido esses escritos. Isso também era parte do segredo. Estavam dispostos a fazer prescriçôes para cada sacrifício e a desenvolver teorias sobre o sacrifício, desde que lhes permitissem. Assim, os professores de antropologia, psiquiatria e pesquisa comportamental tornaram-se teólogos do culto de Baal; e os médicos, seus sacerdotes. Esses antropólogos e psiquiatras diziam que seu problema cientifico era a biologia do ser humano. Dessa forma, na qualidade de teólogos do culto ao extermínio, os outros seres humanos (o judeu, o esquizofrênico, o cigano) se tornavam para eles um enigma aparentemente insolúvel. A solução final e total desse enigma chamava-se genocídio. O avental branco era seu hábito de sacerdote. Médicos com formação antropológica e psiquiátrica receberam a 9 de março de 1943 o direito e o dever de realizar a seleção e a morte das vítimas. Eles lutaram por isso e sacrificaram milhões de pessoas nos altares - os fornos - que erigiram por toda a parte. (...) Auschwitz era o seu imenso santuário. ${ }^{76}$

Müller-Hill, por mais que apresente as evidências do comprometimento científico com o extermínio, também isenta a ciência de sua terrível responsabilidade por meio do efeito atenuador de uma curiosa metáfora. A transformação de psiquiatras e antropólogos em "teólogos do culto de Baal" desempenha esse papel de duas formas: primeiro, por considerar o "erro" como resultante da metamorfose da ciência em religião, intimamente associada ao mito e ao irracional por certas visões da razão; segundo, por sugerir que tal "religião" tinha caráter pagão. Toda a linguagem dessa passagem transporta o leitor para o plano do delírio religioso, para cenas hebraico-cristãs da barbárie pagã como esta:

Desprezaram seus estatutos, bem como a aliança que ele havia concluído com seus pais, e as ordens que lhes havia dado. Correndo atrás da Vaidade, eles próprios se tornaram vaidade, como as naçōes ao redor, apesar de Yahweh lhes ter ordenado que não agissem como elas. Rejeitaram todos os mandamentos de Yahweh seu Deus, fabricaram para si estátuas de metal fundido, os dois bezerros de ouro, fizeram um poste sagrado, adoraram todo o exército do céu e prestaram culto a Baal. Fizeram passar pelo fogo seus filhos e filhas, praticaram a adivinhação e a feitiçaria, e venderam-se para fazer o mal na presença de Iameia, provocando sua ira. Então, Iameia irritou-se sobremaneira contra Israel e arrojou-o para longe de sua face. Restou apenas a tribo de Judá. ${ }^{7}$ 
Escreveu Aristóteles que "bem saber descobrir as metáforas significa bem se aperceber das semelhanças". ${ }^{78}$ A "semelhança", o elemento que torna possível a aproximação de cientistas e "sacerdotes de Baal", é a associação hebraico-cristã daquele culto pagão com o sacrifício humano. No entanto, esse recurso ao mesmo tempo atenua a responsabilidade científica porque auxilia no transporte do problema para o campo religioso, ao qual a "razão" pode atribuir as origens de seu "descaminho". Em vez dos ambientes ascéticos dos laboratórios do Instituto Kaiser Guilherme, da linguagem médica, do entusiasmo sincero de cientistas com o progresso, somos transportados para os cenários do "desvario pagão" assassino.

A defesa da inocência do saber científico racional recebe, já ao final do livro, outro argumento, no qual novamente o mito desempenha papel essencial.

Creio haver demonstrado que não se tratou de falhas de caráter de indivíduos isolados, mas sim de falhas da própria psiquiatria e antropologia.

Toda a ciência construiu-se, no início, sobre fundamentos mitológicos. Depois, com os progressos, foram sendo cortadas aquelas partes que não tinham valor real. Creio já ter demonstrado que a mitologia dos psiquiatras e antropólogos revelou-se, no Terceiro Reich, uma mitologia perniciosa, ou seja, burra e destruidora. Muitos dos psiquiatras e antropólogos por mim citados revelaram-se traidores da sua ciência ao realizar sacrificios com o sangue de inocentes para os seus mitos. ${ }^{79}$

Novo argumento que exime a razão de sua responsabilidade: não teria havido, ao que parece, a devida separação entre mito e razão e, devido a essa falha evolutiva, criara-se uma "mitologia perniciosa". Teria acontecido uma falha intelectual na psiquiatria e na antropologia; ambas não teriam conseguido eliminar seus "fundamentos mitológicos". Graças a estes é que a barbárie imperou em terras europeias. Novamente, o mito serve ao autoengano da razão. Müller-Hill afirma não ter sido o genocídio consequência de uma falha de caráter individual, mas a qualificação final de "traidores da sua ciência" apresenta um caráter moral evidente. A medicina, a psiquiatria, a antropologia... podem manter sua pureza intocada, pois os horrores foram causados por aqueles que não obedeceram aos imperativos éticos que todos conhecemos: aqueles que prescrevem o desenvolvimento do saber para o progresso e bem-estar da humanidade.

O sociólogo Zygmunt Bauman provavelmente classificaria esse gênero de argumento com uma das formas de "autocura da memória histórica" ocidental, uma autocura equivocada e potencialmente suicida. Para o intelectual polaco de origem judaica, ex-soldado do Exército Vermelho na Segunda Grande Guerra, cuja esposa sobreviveu ao Holocausto, este somente pode ser compreendido como fruto da civilização ocidental e da modernidade. Houve elementos outros, como o antissemitismo alemão e europeu, mas elementos cruciais para a eliminação de "seres indignos de viver" foram produzidos pela modernidade. A começar pela promoção do Estado à posição de ator privilegiado para ação sobre a sociedade concebida com um "jardim", do qual deveriam ser retiradas as "ervas daninhas" que prejudicavam a aparência e ameaçavam a sobrevivência do "organismo social". Não devemos, contudo, nos tranquilizar com a acusação ao "aparelho estatal", porque a ideia do extermínio sistemático não seria possível sem as tendências culturais e realizaçôes técnicas da modernidade e do "processo civilizador". ${ }^{80}$ Essa noção, de Norbert Elias, é um dos objetos centrais da crítica de Bauman. Em sua opinião, é uma das noçôes doutas confirmadoras do "mito aitiológico" arraigado na consciência da "nossa sociedade ocidental": a de que nosso caminho pode ser reduzido à "história moralmente edificante da humanidade emergindo da barbárie pré-social". ${ }^{81}$ Trata-se de uma virada radical: Bauman emprega a maleável noção de mito para reduzir a concepção do avanço da razão e das luzes à condição de "estória edificante e ilusória", confortante e equivocada, um "mito legitimador" da hegemonia ocidental sobre o planeta. ${ }^{82} \mathrm{~A}$ crítica ao evolucionismo, à ideia de progresso, não é nova. A radical novidade do pensamento de Bauman é fazer de nosso modo de vida o responsável pelo extermínio em larga escala, racionalmente planejado e executado. A ciência, argumenta, apoiou direta e indiretamente o que, em nossos sonhos confortantes, é a missão do saber racional: o aprimoramento da vida. Ela teve um "papel som- 
brio e ignóbil" durante o Holocausto, solapando, indiretamente, a autoridade e questionando a força aglutinadora de todo o pensamento normativo, particularmente da religião e da ética. A consequência disso foi a eliminação de qualquer consideração moral por parte dos cientistas, que puderam cooperar com entusiasmo no desenvolvimento de métodos de esterilização e no uso de escravos dos campos de concentração como cobaias de suas experiências. Diretamente, concebendo seu trabalho como movido apenas pela curiosidade desinteressada da pesquisa da verdade, desprovida de juízos de valor. Os cientistas, "com prazer", puderam tomar o trem puxado pela locomotiva nazista rumo a um bravo, novo e purificado mundo da dominação germânica. ${ }^{83}$

Por isso, Bauman pode parodiar o lugar-comum de nossa forma de pensar a relação entre civilização e barbárie na citação que abre este artigo:

O mundo hobbesiano do Holocausto não veio à tona saindo de sua sepultura rasa demais, ressuscitado pelo tumulto das emoções irracionais. Apareceu (...) num veículo de produção industrial, empunhando a arma que só a ciência mais avançada poderia fornecer e seguindo um itinerário traçado por uma organização cientificamente administrada. A civilização moderna não foi a condição suficiente do Holocausto; foi, no entanto, com toda a certeza, sua condição necessária. Sem ela, Holocausto seria impensável. Foi o mundo racional da civilização moderna que tornou viável o Holocausto. ${ }^{84}$

A interpretação de Bauman é resumida de forma admirável nesse parágrafo satírico. Em vez de uma episódica derrota da razão no eterno combate contra a irracionalidade ressurrecta pelas paixões humanas, temos o Holocausto intimamente conectado com a modernidade racionalista. Isso acarreta uma revisão completa de nossa ideia progressista da história, há muito criticada - o próprio autor relembra uma passagem marcante de Walter Benjamim ${ }^{85}$-, mas que se revela persistente em nossas reflexôes sobre a história, a razão e a ciência. Bem o demonstra Zygmunt Bauman em sua "revisão bibliográfica": a destruição sistemática de seres humanos é comumente vista como um acidente da história moderna. A Igreja Católica, nos últimos tempos, tem expressado pesar e arrependimento por suas faltas humanas e solicitado perdão por seus terríveis erros. A razão e a ciência, por seu turno, parecem sempre contar com o argumento de que seus erros e crimes correspondem a deturpações de suas intençôes e verdades ou à ação de seus adversários eventualmente vitoriosos, depois de "ressuscitados" pela parte irracional da alma humana. Inimigos históricos nesse argumento simplório, o mito e a mitologia têm se prestado ao autoengano da razão, pois são comumente associados à barbárie pagã, ao primitivo, ao emocional. Os desvarios da razão podem ser atribuídos a esses tradicionais adversários das Luzes, pois estas, "por definição", são incapazes de realizaçōes abomináveis. Nessas situaçōes, a ideia de verdade científica efêmera, humana, parece ser esquecida em favor de uma noção divinizante. O pensamento, contudo, pertence ao humano mundo das aparências, sendo sujeito às limitações da condição humana. A não ser que descubramos um ponto privilegiado, que nos proporcione uma perspectiva inconteste, o significado do que pensamos, suas implicaçôes e consequências, permanecerão carregando consigo as alternativas de risco, de engano, do terrífico.

A tragédia grega, de forma geral, mostrara como o caráter da ação humana não tinha, a priori, qualquer sentido garantido:

O que a tragédia traz à vista de todos - não "discursivamente", mas por apresentação [destaque original] é que o Ser é Caos. O Caos apresenta-se aqui, primeiramente, como a ausência de ordem para o homem, a falta de correspondência positiva entre as intençôes e açôes humanas, por um lado, e seus resultados e consequências de nossos atos, mas também que não dominamos nem mesmo a sua significaçãoo ${ }^{86}$

De forma semelhante, Bauman menciona a conclusão de Klaus Hilberg, historiador do Holocausto, de que "nossas instituiçóes sociais mais decisivas nos escapam ao controle prático e ao alcance mental". ${ }^{87}$ Como qualquer criação humana, as racionais podem apresentar desenvolvimentos impensados; o próprio significado daquilo que é propugnado pela razão pode escapar à consciência de seus criadores. 
Deveríamos assim, nos preocupar, todos, com o que experiências, como a do Holocausto, podem revelar para a concepção que fazemos da razão e da ciência e sua cegueira peculiar. Assim, talvez, pudéssemos avaliar nosso pensamento racional de um ponto de vista que revelasse seu caráter humano. Alternativamente, seu estudo, assim como o de outras críticas intelectuais às mazelas coletivas, poderia também contribuir para o entendimento daquilo que insistimos em designar como "mito" e "mitológico", do seu papel no ocultamento dos desvarios do saber iluminado e na própria autodefinição deste.

\section{Notas}

${ }^{1}$ BAUMAN, Zygmunt. Modernidade e holocausto. Rio de Janeiro: Zahar, 1998, p. 32. Os destaques da citação são de Z. Bauman. No restante deste texto, salvo observação em contrário, os destaques são de minha autoria.

${ }^{2}$ Uma primeira versão deste texto foi apresentada no Seminário de Pesquisas "Antigo e Modernos: diálogos sobre a (escrita da) história", promovido pelo Departamento de História da Universidade de São Paulo (USP), coordenado pelos colegas Francisco Murari Pires e Marlene Suano e realizado em setembro de 2007. Posteriormente, um pouco modificado, foi apresentado no "Seminário Permanente de Estudos Clássicos", promovido pelos Laboratórios OUSIA (do Programa de Pósgraduação em Filosofia da Universidade Federal do Rio de Janeiro) e Programa de Altos Estudos em Representações da Antiguidade (PROAERA) da mesma universidade. Os dois laboratórios são coordenados, respectivamente, pelos colegas Fernando Santoro e Henrique Cairus, aos quais agradeço a oportunidade de expor meu trabalho naquela instituição, no final do mesmo mês de setembro de 2007.

3 "A perspectiva da 'razão nobre', que não é outra senão a do senso comum, parte do princípio de que estamos nas melhores condiçôes para decidir e somos o orgulho de Platão, Descartes e Kant quando deixamos a lógica formal conduzir-nos à melhor solução para o problema." DAMÁSIO, A. R. O erro de Descartes. Emoçãa, razão e o cérebro humano. São Paulo: Companhia das Letras, 1996, p. 203.

${ }^{4}$ DETIENNE, Marcel. A invenção da mitologia. Rio de Janeiro: Zahar, 1992; CALAME, Claude. Mythe et histoire dans l'Antiquité Grecque. La création symbolique d'une colonie. Lausanne: Payot, 1996. A pesquisa contou com o apoio da Fundação de Amparo à Pesquisa (FAPERGS), que concedeu Auxílio Recém-doutor; do Conselho Nacional de Pesquisa (CNPq) e Pró-reitoria de Pesquisa da UFRGS (PROPESQ), que concederam bolsas de iniciação científica. A PROPESQ/UFRGS ainda possibilitou a aquisição de algumas obras para o projeto. Registro também que este texto resulta do trabalho das bolsistas, então alunas de graduação, Marisângela Martins, Michele Bonato e Deise Zandoná.

${ }^{5}$ GINZBURG, Carlo. Olhos de madeira. Nove reflexōes sobre a distância. São Paulo: Companhia das Letras, 2001, p. 42-84. C. Ginzburg também cita as obras de Gregory Nagy (1979) e de Paul Veyne (1984). No caso deste último, a argumentação, creio, é de caráter diverso. Veyne é crítico, como outros historiadores, da ideia de que haja objetos de estudo "naturais", eternos e invariáveis através dos tempos. Não há denúncia do aspecto etnocêntrico de mito e mitologia e a proposição do abandono dessas categorias, mas a desconsideração da possibilidade de que "mito" possa ter - assim como qualquer outro conceito - existência universal, perene e, por consequência, significado invariável. Em "Foucault revoluciona a história" (1978), Paul Veyne explicita essa posição, anteriormente apresentada em Como se escreve a história, a partir da avaliação do significado histórico da obra do seu particular colega. Cf. VEYNE, P. Foucault révolutione l'histoire. In: Comment on écrit

l'histoire. Paris: Seuil, 1971, p. 383-429. A versão brasileira deste texto, assim como a de "Como se escreve...",. é péssima, pelo menos a da primeira edição; da versão portuguesa (Edições 70) não consta o ensaio sobre Foucault.

${ }^{6}$ GINZBURG, C. Op. cit., p. 84.

${ }^{7}$ Idem, 42-43.

${ }^{8}$ VERNANT, Jean-Pierre. Fronteiras do mito. In: FUNARI, Pedro Paulo (org.). Repensando o Mundo Antigo. Campinas: UNICAMP, 2005, p. 13. Depois dessa constatação, Vernant empreende sucinto retorno aos gregos: indicando sua dívida para com a análise de M. Detienne (1992), destaca a compatibilidade de mito e logos na primeira filosofia; a heterogeneidade das narrativas consideradas como mito por Platão; a desclassificação tucidideana dos relatos de poetas e logógrafos, ditos mitológicos pela distância temporal de seu conteúdo; e a constituição da mitologia, no século II a.C, quando foi criado um novo campo de estudo, constituído por diversas iniciativas avaliadoras de antigos relatos, distintos da história, poesia, filosofia e demais gêneros então reconhecidos (Idem, p. 14-24). Resta, ao final do exame de Vernant, a compreensão desta história, mas não a reafirmação da universalidade dos antigos significados ou a afirmação de novos entendimentos generalizáveis de mito, mitologia e pensamento mítico.

${ }^{9}$ O título da primeira obra, de 1907, era, e ainda é, particularmente provocador: "Thucydides Mythistoricus", pois o historiador ateniense foi e, é, muitas vezes considerado o predecessor privilegiado da concepção racional, moderna, de história. Duas citaçōes exemplares: "Se, todavia, podemos discernir em Heródoto o nascimento de um sentido histórico, não podemos fechar os olhos para a considerável quantidade de passagens em que ele reconhece influências sobrenaturais como parte das forças comuns da vida. Comparado com Tucídides, que o sucedeu no desenvolvimento da história, ele parece mais com 
um escritor medieval do que com um moderno racionalista. Porque, apesar de contemporâneos, entre os dois autores há um infinito abismo de pensamento." (WILDE, Oscar. The rise of historical criticism, p. 20. Disponível em <http://www.ucc.ie/ celt/online/E800003-001/>. Acesso em 24 abr. 2009. O texto foi escrito em 1879.); "Heródoto pode ou não ter 'inventado' a história. (...) Este estudo começa com, e sempre tem em mente, Heródoto, mas seu foco principal é sobre Tucídides, o historiador ateniense [que], para o melhor e pior, fez muito para definir o que foi entendido por 'bistória' nos dois mil anos seguintes." (CRANE, Gregory. The blinded eye. Thucydides and the new written word. Boston: Rowmann \& Littlefield, 1996, p. 1). As referências dos trabalhos de F. Cornford estão na bibliografia.

${ }^{10}$ LÉVI-STRAUSS, C. O pensamento selvagem. Trad. Tânia Pellegrini. Campinas: São Paulo, 1989(1962), p. 31.

${ }^{11}$ GOODY, Jack. Domesticação do pensamento selvagem. Lisboa: Editorial Presença, 1988.

${ }^{12}$ C. Calame reconhece seguir o caminho das investigaçōes de M. Detienne (1981) e Paul Veyne (1988). Cf. CALAME, C. The rhetoric of mythos and logos: forms of figurative discourse. In: BUXTON, Richard (ed.). From myth to reason? Studies in the development of greek thought. Oxford: Oxford UP, 1999, p. 123, nota 5.

${ }^{13}$ Assim, foi registrado como "mito" o discurso de Zeus na assembleia dos deuses que abre o canto VIII da Ilíada, quando os imortais são advertidos para não mais interferirem da luta entre dânaos e troianos: "Falou. Todos calaram, pasmos, ante o duro discurso [mythos]." (HOMERO. Iliada, VIII, 29).

${ }^{14}$ VERNANT, Jean-Pierre. Mito y sociedad en la Grecia antigua. 2 ed. Madrid: Siglo Veintiuno, 1987, p. 170. Depois de analisar a história do surgimento da noção negativa de mito entre os gregos, Vernant concluíra pela necessidade de distanciamento da tradição então nascida e, sobretudo, pelo abandono da noção que supunha os mitos helenos como modelos, partindo-se então para o estudo comparativo com narrativas de "grandes civilizações não clássicas e com os povos ágrafos" (p. 189).

${ }^{15}$ É Detienne que se refere aos europeus como "indígenas": "O terreno onde poderemos descobrir melhor os estranhos pensamentos que a mitologia desperta em nós é uma 'etnia' ainda mal estudada do ponto de vista etnográfico uma vez que ela é maravilhosamente rica em modelos antropológicos. Trata-se da sociedade dos cristãos do ocidente, muito presos a um conjunto de textos chamado Testamento [itálico do autor]. Com efeito, entre as décadas de quarenta e cinquenta deste século, sábios indígenas, conhecidos pelo nome de teólogos, mantiveram longa disputa sobre a natureza do mito e do bom uso da mitologia." DETIENNE, M. A escrita de Orfeu. Rio de Janeiro: Jorge Zahar, 1991, p. 116.

${ }^{16}$ Relembrando sua carreira em entrevista, Vernant ressalvou que discordava do entendimento de Lévi-Strauss sobre a existência de uma "atividade mental" universal, assim como de sua compreensão "a-histórica" do mito. Concordava com Dumézil e Lévi-Strauss quando esses afirmavam ser preciso mostrar a organização, as ressonâncias internas decorrentes da sistematicidade de um "texto dito mítico ou lendário, uma narrativa ou texto de Hesíodo". Seu problema em particular, porém, era o de tentar "verificar como esses sistemas se transformam, como esses sistemas - não importa que sistema, em realidade - comportam níveis diferenciados: as camadas de tempo não são as mesmas; há portanto, dissonâncias e contradiçōes. Isso faz o sistema desmoronar." VERNANT, J-P. Como um barco à deriva. Três colegas do Collège de France. Teoria \&u pesquisa: Revista de Ciências Sociais, São Carlos, v. XVI, n. 2, jul./dez. 2007. Entrevista concedida a José Otávio Nogueira Guimarães. p. 180-182. Disponível em: <http://www.teoriaepesquisa.ufscar.br/index.php/tp/article/viewFile/113/90>. Acesso em 30 abr. 2009.

${ }^{17} \mathrm{O}$ que os gregos designavam como "mitos" seriam narrativas com características figurativas determinadas pelos enredos específicos de cada uma delas, nunca implicando em um modo de pensamento. Cf. CALAME, C. The rhetoric of mythos..., p. 140-141.

${ }^{18}$ Igual proposição foi feita por Geoffrey Lloyd ao final de seu texto sobre "mitologia chinesa". LLOYD, G. Mythology: reflections from a chinese perspective. In: BUXTON, R. Op. cit., p. 164-165.

${ }^{19} \mathrm{O}$ que não surpreenderia Paul Veyne, para quem a história, como qualquer saber intelectual, tem escasso ou nulo impacto fora dos estreitos limites de seu universo (VEYNE, P. Como se escreve a história. Lisboa: Edições 70, 1981, p. 87-104). É mais difícil explicar a relativa indiferença do mundo acadêmico.

${ }^{20}$ SERRA, Ordep. A antropologia, a mitologia e sua escrita. Clássica. São Paulo, v. 11/12, 1998/1999. p. 27.

${ }^{21}$ Ao apresentar seu trabalho em $A$ inconstância da alma selvagem, o antropólogo brasileiro Eduardo Viveiros de Castro escreve ser preciso lutar "com os automatismos intelectuais de nossa tradição" e "com os paradigmas descritivos e tipológicos produzidos pela antropologia a partir de outros contextos socioculturais" para criar uma linguagem analítica "à medida (à altura) dos mundos indígenas" que estuda. CASTRO, Eduardo Viveiros de. A inconstância da alma selvagem. São Paulo: Cosac \& Naify, 2002, p. 15.

${ }^{22}$ PLATÃO, Teeteto, $164 \mathrm{~d}$.

${ }^{23}$ PLATÃO, Teeteto, 173d-e.

${ }^{24} \mathrm{O}$ núcleo urbano da pólis, com os espaços centrais de todas as atividades públicas e privadas, delimitado pelas muralhas que o separavam da zona rural da cidade antiga.

${ }^{25}$ Diálogo silencioso da "alma consigo mesma" ou, resguardando a ideia de multipolaridade presente no termo diálogos: interlocução interior e silenciosa de um indivíduo com um alter ego ou com um receptor imaginário. Cf. GUERREIRO, 
Mario A. Repensando o conceito platônico de dianoia. Revista Princípios-Depto de Filosofia/UFRN, Natal, v. II, n. 1, junho 1995. p. 132. Disponível em: <http://dialnet.unirioja.es/servlet/articulo?codigo=2565595>. Acesso em 28 fev. 2009.

${ }^{26}$ PLATÃO, Teeteto, $173 \mathrm{e}-174 \mathrm{a}$.

${ }^{27}$ Dedicação que teria sido preliminarmente prescrita por Parmênides em seu famoso poema, já considerado como "fonte de toda a ontologia platônico-aristotélica sob a qual vivemos” (CASSIN, Barbara. O efeito sofístico. São Paulo: 34, 2005, p. 17). Logo no início do mesmo, tal como transmitido através dos tempos (e na tradução de Fernando Santoro), a Deusa teria estabelecido as tarefas do jovem filósofo, que a ela chegara trilhando o "caminho apartado dos homens":

Mas é preciso que de tudo te

instruas: tanto do intrépido coração da Verdade persuasiva

quanto das opiniões de mortais em que não há fé verdadeira.

Contudo, também isto aprenderás: como as opiniōes

precisam patentemente ser, atravessando tudo através de tudo.

(Da natureza, Frag. B1, 28-32)

Discute-se a importância reservada ao mundo dos comuns mortais nesta e em outras passagens do poema (como o Frag. B7). As opiniōes do vulgo poderiam ser de alguma importância para merecer a atenção do filósofo, já que ao jovem aprendiz é dito que sua aprendizagem as incluiria. Cf. McKIRAHAN JR., Richard D. Philosophy before Socrates: an introduction with texts and commentary. Cambridge: Hacket, 1994; PARMÊNIDES. Da natureza. São Paulo: Loyola, 2002.

${ }^{28}$ Especialmente aqueles atos de "caráter servil" (doulikos): amarrar os cobertores para uma viagem, temperar alimentos, "fazer discursos bajulatórios" (PLATÃO, Teeteto, 175e).

${ }^{29}$ PLATÃO, Teeteto, $174 \mathrm{a}-\mathrm{d}$.

${ }^{30}$ Não se trata de delírio ou patologia, mas são falaciosas. A posição de H. Arendt é clara: "A falácia lógica elementar de todas essas teorias que se apoiam em uma dicotomia entre o Ser e a Aparência é óbvia e foi logo descoberta e resumida pelo sofista Górgias, em um fragmento que se conservou de seu desaparecido tratado Sobre o não-ser ou sobre a natureza - provavelmente uma refutação da filosofia eleática: 'O ser não é manifesto, já que não aparece [para nós: dokein]; o aparecer (para nós) é fraco, já que não consegue ser.” (Cf. ARENDT, H. A vida do espirito. O pensar. O querer. O julgar. Rio de Janeiro: Relume Dumará, 1992, p. 22-23). A citação interna é de ARISTÓTELES, De anima, 433a30. Essa discussão pode parecer estranha aos domínios da história, mas pode auxiliar seus estudiosos a situar, na história da epistemologia, a polêmica sobre a relevância da narrativa e da retórica para a sua disciplina. C. Ginzburg por exemplo, simpático à posição eleático-platônica, retorna à Grécia Antiga para expressar sua posição condenatória às transformações causadas pela repercussão de ideias como as de Hayden White no domínio do historiador. O elo intermediário dessa cadeia de erros epistemológicos - com graves repercussões morais, segundo ele - é Friederich Nietzsche. (Cf. GINZBURG, C. Relações de força. São Paulo: Companhia das Letras, 2002, p. 13-45). Em certas passagens, o historiador italiano parece confundir sofistas e céticos, duas categorias diversas de filósofos. Os segundos não negavam a existência de uma dimensão última e verdadeira, apenas duvidavam da capacidade humana de apreendê-la. Esta distinção pode ser avaliada na obra de Barbara Cassin, citada na nota 25.

${ }^{31}$ Idem, p. 89.

${ }^{32}$ Crítico radical da cosmologia dos "dois mundos", F. Nietzsche escreveu: "Em todos os tempos, os homens mais sábios fizeram o mesmo julgamento da vida: ela não vale nada...Sempre, em toda parte, ouviu-se de sua boca o mesmo tom - um tom cheio de dúvida, de melancolia, de cansaço da vida, de resistência à vida. Até mesmo Sócrates falou, ao morrer: 'Viver - significa há muito estar doente: devo um galo a Asclépio, o salvador'. (...) O que prova isso? O que indica isso? Antigamente se teria dito (...) 'De todo modo, deve haver alguma verdade nisso! O consensus sapientium [consenso dos sábios] prova a verdade'. Ainda falaremos assim hoje? Podemos falar assim? 'De todo modo, deve haver alguma doença nisso' - é o que nós respondemos: esses sábios de todos os tempos, é preciso observá-los de perto!(...) Talvez a sabedoria apareça na Terra como um corvo, que se entusiasma com um ligeiro odor de cadáver?...”. Considerando que juízos de valor sobre a vida nunca podem ser verdadeiros, Nietzsche vaticinou que eles deveriam ser interpretados como "sintomas". Concluiu que, no caso socrático, aqueles julgamentos deveriam ser vistos como sintoma da decadência do mundo grego - decadência, naquele tempo era o conceitolugar-comum para interpretar a história. NIETZSCHE, F. O problema de Sócrates. In: . Crepúsculo dos Ídolos, ou, como se filosofa com o martelo. São Paulo: Companhia das Letras, 2006, p. 17 e ss. Todos os destaques da citação são originais.

${ }^{33}$ ARENDT, H. Op. cit., p. 66 e ss.

${ }^{34}$ Platão, Carta $7^{a}, 328 \mathrm{c}-\mathrm{d}$. A autenticidade desta carta, como das demais, é discutida por muitos. Luc Brisson a considera legítima. Cf. BRISSON, L. Leituras de Platão. Porto Alegre: EDIPUCRS, 2003, p. 23-34.

${ }^{35}$ ARISTÓTELES, Retórica, I 5, $1360 \mathrm{~b}$.

${ }^{36}$ ARISTÓTELES, Retórica, I 7, $1364 \mathrm{~b}$.

${ }^{37}$ CÍCERO, Dos Deveres, IX, 28.

${ }^{38}$ Outro aspecto interessante seria explorar as possíveis relações entre essa concepção dualista e a noção de estrutura, cara aos historiadores. Penso particularmente na investigação do demérito das aparências implicado pelas ideias estruturalistas. 
Muitas vezes, a hierarquização de fatores nos leva a pensar que as explicaçôes "profundas" realmente estão numa dimensão metafísica. Um bom exemplo: "A maior recompensa que o autor deste livro poderia ter é convencer o leitor de que uma primeira tarefa da atividade histórica é a de distinguir, no fluxo dos acontecimentos de cada instante da civilização, aquilo que pertence às estruturas, na longa duração, até mesmo a uma natureza eterna, e aquilo que, ao contrário, caracteriza a particularidade de um tempo e de um momento." Agradeço a Bibiana Soldera Dias pela indicação desta passagem de: BERCÉ, Yves-Marie. O Rei oculto: salvadores e impostores. Mitos políticos populares na Europa moderna. Bauru: EDUSC; São Paulo: Imprensa Oficial do Estado, 2003, p.10.

${ }^{39}$ ARENDT, H. Op. cit., p. 61.

${ }^{40}$ GEERTZ, C. A interpretação das culturas. Rio de Janeiro: Zahar, 1978, p. 137 e ss.

41 "Nossa vida cotidiana compõe-se de um grande número de programas de verdade e a impressão de mediocridade cotidiana surge justamente desta pluralidade que, em certos estados de escrúpulo neurótico, é sentida como uma hipocrisia; passamos sem cessar de um programa para outro, como se muda de comprimento de onda no rádio, mas nós o fazemos sem sabê-lo." (VEYNE, P. Acreditavam os gregos em seus mitos. São Paulo: Brasiliense, 1984, p. 101-102.). O historiador francês criou a imagem da "balcanização de cérebros" para resumir a multiplicidade de dimensōes da vida dos indivíduos; C. Geertz escreveu sobre as "formas radicalmente contrastantes de ver o mundo, formas que não são contínuas umas com as outras, mas separadas por fossos culturais que devem ser transpostos em saltos kiekergaardianos em ambas as direções (...)”. GEERTZ, Clifford. Op. cit, p. 137.

${ }^{42}$ GINZBURG, C. Olhos de madeira, p. 83.

${ }^{43}$ Nas telas dos cinemas, a guerra voltou a ter sentido em filmes como "Fomos heróis" (2002), título em português para "We Were Soldiers/We Were Soldiers Once... and Young" ("Fomos soldados/Um dia fomos soldados...e jovens"), dirigido por Randall Wallace e estrelado por Mel Gibson. O contraste com outros filmes sobre o Vietnã, como "Platton", é radical.

${ }^{44}$ HOBSBAWM, E. Dentro e fora da história. In: . Sobre História. São Paulo, Companhia das Letras, 1998, p. 19-20.

${ }^{45}$ Quando A. Damásio se refere à perspectiva comum da razão nobre e do senso comum, seu objetivo é destacar: "Um aspecto importante da concepção racionalista é o de que, para alcançar os melhores resultados, as emoções têm de ficar de fora. O processo racional não deve ser prejudicado pela paixão" (DAMÁSIO, A. Op. cit., p. 203). Como se sabe, na antiguidade, gregos, romanos e cristãos contribuíram, cada qual a seu modo, para a demonização das "paixões". Quanto aos helenos: "A verdade é que a alma está dividida entre esses dois logoi já em Platão, e que aí se trama o jogo das paixões, dos desejos sensíveis, embora estes não façam, verdadeiramente, parte do logos. Daí a alegoria, o mito e as imagens a que Platão recorre no Fedro para falar do que escapa à razão, do que se lhe opõe e que deveria também poder, apesar de tudo, voltar a ela. A alma é comparada a animais atrelados, conduzidos por um cocheiro que tenta harmonizar os puxões dos cavalos que se lançam em direções opostas. Eles simbolizam de fato o apetite sensível e a força de resistência a esse apetite, enquanto o cocheiro representa o julgamento da razão sã." MEIER, Michel. "Prefácio. Aristóteles ou a retórica das paixões". In: FONSECA, Isis Borges B da (Introdução, notas e tradução do grego). Aristóteles. Retórica das paixōes. São Paulo: Martins Fontes, 2000, p. XX-XXI. A passagem do Fedro platônico referida por Meier é 246 a-c.

${ }^{46}$ Parece que nosso estatuto nos impõe uma obrigação de dificílima realização, a ponto de considerar um esforço malfadado como suficiente.

${ }^{47}$ HOBSBAWM, E. Naçôes e nacionalismo. Programa, mito e realidade. Rio de Janeiro: Paz e Terra, 1990, p. 22.

${ }^{48} \mathrm{~A}$ literatura sobre o Holocausto apresenta indícios da importância dos elos coletivos nacionais, talvez porque o desenraizamento tenha sido uma das estratégias das ações do extermínio. Acolhida em um lar inglês aos 12 anos graças a um movimento que procurou salvar crianças judias da perseguição alemã nazista, Inge Pollack registrou em seu diário sentimentos contraditórios para com seus salvadores: sabia dever a eles gratidão, mas a saudade dos pais e da terra natal a irritava, a fazia rebelde e melancolicamente infeliz: "Sinto que fui arrancada do meu próprio ninho acolhedor e isso dói terrivelmente (...) Estou num país estrangeiro, e não mais em casa. Se alguém me corrige, imediatamente penso no pior; querem me irritar, odeiam-me. Então digo a mim mesma: 'Essas pessoas são desconhecidas. O que elas têm a ver com você?? Esse não é seu país. Não nasceu aqui, e consequentemente aqui não é o seu lugar'." Inge perdeu avó e mãe, mortas nos campos, sobreviveu apesar disso, cresceu e reconheceu a Inglaterra como seu novo lar, onde casou e viveu. (FILIPOVIC, Zlata; CHALLENGER, Melanie (eds.). Vozes roubadas. Diários de guerra. São Paulo: Companhia das Letras, 2008, p. 112-113) A importância do "enraizamento" em uma coletividade, conceituado por Simone Weil, é ressaltada por Fernando Frochtengarten, psicólogo social que dissertou sobre a viagem de retorno de seu avô materno, judeu, à cidade natal polonesa, da qual foi afastado pela Segunda Guerra. $\mathrm{O}$ homem precisaria do enraizamento em grupos para ter a memória do passado que permite a existência no presente. Cf. Memórias de vida, memórias de guerra. Um estudo psicossocial sobre o desenraizamento. São Paulo: Perspectiva, 2005, p. 3-21.

${ }^{49}$ Afirmada já em texto de 1957, "A formação do pensamento positivo na Grécia Arcaica", no qual rendeu homenagem a F.M. Cornford e defendeu que a distinção do pensamento racional consiste na separação entre as dimensōes humana, natural e divina, e na recusa da ambiguidade mítica em favor do princípio da identidade (In: VERNANT, J-P. Mito e pensamento entre os gregos. Rio de Janeiro: Paz e Terra, 1990, p. 358). Na direção oposta, essa separação foi vista pelo sociólogo Gabriel Tarde como um dos elementos que nos torna cegos para a multiplicidade do mundo. Nas palavras de Eduardo V. Vargas, 
nosso espírito vagaria cego desde sua libertação das sombras da caverna (de Platão) e seria necessário romper com a concepção radicada na identidade do ser para vermos a pluralidade: "não somos capazes de dizer nada além da nossa experiência quando dizemos 'somos.” VARGAS, Eduardo Vianna. Gabriel Tarde e a diferença infinitesimal. In: (org.). Gabriel Tarde. A monadologia e outros ensaios. São Paulo: Cosac Naify, 2007, p. 24, 34.

50 "De uma teologia, ou ao menos uma metafísica da Razão, passamos para algo completamente diferente: uma história das formas de pensamento racional em sua diversidade, suas variaçôes, suas transformaçôes mais ou menos profundas. O que o historiador chama de razão são modos definidos de pensamento, disciplinas intelectuais, técnicas mentais próprias a campos particulares da experiência e do saber. Formas diversas de argumentação, de demonstração, de refutação, modos particulares de inquérito sobre os fatos, de administração da prova e das provas, diferentes tipos de verificação experimental". (VERNANT, Jean-Pierre. Entre mito e política. São Paulo: EDUSP, 2001, p.192). A razão helênica - teórica, imanente à linguagem - seria muito diversa da razão matemática contemporânea, da razão experimental da ciência; estaria, porém, presente na maior parte da vida social, na filosofia, na política: "Em vez de pesquisar a partir do real para entender em que medida nossas teorias dão conta dele, ela se dá como tarefa elaborar, no nível do discurso, uma argumentação no fim da qual todos os problemas parecem resolvidos, todas as contradições desaparecidas ou ultrapassadas". Seria um "razão verbal". (Idem, p. 195). Haveria também outras racionalidades: as dos babilônios, chineses, cada qual permitindo ação em determinados planos e vedando, assim, outros (Idem, p. 209-210).

${ }^{51}$ Idem, p. 216-217. "Astrologia" e "comunicação de pensamento" são os domínios do irracional mencionados por Vernant. Já o mito foi considerado como dotado de "certa racionalidade", distinta daquela encontrada no discurso dos sofistas e na crença dos filósofos (Idem, p. 206).

52 As elucubrações baseadas nessa perspectiva dualista apresentam elementos que caracterizam uma verdadeira "retórica do combate". Porque a razão, a despeito de sua admirável luminosidade, é vulnerável a um inimigo que, mesmo derrotado, permanece ameaçador, precariamente restrito aos "subterrâneos" da ordem. Esses podem ser um "subterrâneo mítico", ou o interior da psique, ou da natureza humana. Dessas regiōes, o irracional pode novamente "invadir" a dimensão iluminada pelo lógos. A "retórica do combate", em algumas de suas diversas versōes, foi objeto de análise durante o projeto "Lógos versus mito" e resultou em apresentaçōes cujo texto permanece inédito. Oudemans e Lardinois trataram da difícil relação do racionalismo com a ideia da desordem em Tragic Ambiguity (Leiden: Brill, 1987).

${ }^{53}$ Uma alternativa intelectual e existencial pode ser o ceticismo tal como concebido por Oswaldo Porchat de Oliveira. Um indício: "Proponho uma ruptura bem mais radical que a do ceticismo. Um mergulho profundo, definitivo e de alma inteira na vida cotidiana dos homens. Não me limito a suspender meus juízos mas, em face dos jogos filosóficos, ouso dizer: 'Não jogo mais'. Regresso à humanidade comum e assumo integralmente a sua não-filosofia.” Vida comum e ceticismo. São Paulo: Brasiliense, 1994 , p. 50.

${ }^{54}$ CASTORIADIS, Cornelius. A pólis grega e a criação da democracia. In: As encruzilhadas do labirinto/2. Os dominios do homem. Rio de Janeiro: Paz e Terra, 1987, p. 269.

${ }^{55}$ A irritação de Castoriadis se revela na continuação da citação: "que se põem [os etnólogos], neste particular grupo de tribos que é o nosso, a exorcizar as tribos estrangeiras ou a submetê-las a algum outro tratamento - a única diferença é que, em vez de aniquilá-las por fumigação, eles a aniquilam por estruturalização (sic)”. Idem, p. 270.

${ }^{56}$ Idem, p. 268.

${ }^{57}$ Idem, p. 275. Os destaques da citação são originais.

${ }^{58} \mathrm{Da}$ sua arte o engenho subtil

para além do que se espera, ora o leva

ao bem, ora ao mal;

se da terra preza as leis e dos deuses

na justiça faz fé, grande é a cidade;

mas logo a perde

quem por audácia incorre no erro. (SÓFOCLES, Antígona, v. 365-373)

Houvesse condiçōes de perceber, com segurança, o que é o "bem" e o "mal"... ou se houvesse este "bem" e este "mal" absolutos, a condição humana seria incapaz de gerar dramas como os trágicos. A tradução acima é de Maria Helena Rocha Pereira.

${ }^{59}$ MÜLLER-HILL, B. Ciência assassina. Rio de Janeiro: Xenon, 1993, p. 7.

${ }^{60}$ Idem, p. 8-9.

${ }^{61}$ Idem, p. 10.

${ }^{62}$ Idem, p. 9.

${ }^{63}$ WEIGMANN, Katrin. In the name of science. European Molecular Biology Organization (EMBO) Reports. Heildelberg: EMBO, 2001, p. 874. Disponível em <http://www.pubmedcentral.nih.gov/articlerender.fcgi?tool=pubmed\&pubmedid= 11600445>. Acesso em 08 jan. 2009.

${ }^{64}$ Carnegie Institution for Science. Disponível em <http://www.ciw.edu/>. Acesso em 16 agosto 2009. 
${ }^{65}$ BLACK, Edwin. A guerra contra os fracos: a eugenia e a campanha dos Estados Unidos para criar uma raça dominante. São Paulo: A Girafa, 2003, p. 83 e ss., 489 e ss. A Sociedade Imperador Guilherme - fundada em 1911 -, atual Sociedade Max Planck, foi responsável pela criação da "Oxford alemã" sonhada pelo subsecretário prussiano de Assuntos Culturais Friedrich Althoff. Financiou a construção de prédios para diversos institutos de pesquisa científica, entre eles o do Instituto Imperador Guilherme de Antropologia, Ciência da Hereditariedade Humana e Eugenia. Em 1948, a Universidade Livre de Berlim incorporou os prédios e o passado de comprometimento daquelas instituições com o nazismo. No edifício da instituição de pesquisa eugênica foi colocada uma placa relembrando o seu vergonhoso passado. Cf. $<$ http://www.fu-berlin.de/en/tour/geschichtsausstellung/geschichte/kwi_anthro/index.htm>l. Acesso em 8 jan. 2009.

${ }^{66}$ Documentos digitalizados da principal instituição norte-americana de pesquisa eugênica podem ser consultados no sítio Image Archive on the American Eugenies Movement, disponível em <http://www.eugenicsarchive.org/eugenics/list_topics. pl?theme $=25 \&$ search $=\&$ matches $>$. Acesso em 10 jan. 2009.

${ }^{67}$ BLACK, E. Op. cit., p. 41-306; 385-400; DIWAN, Pietra Stefânia. Raça pura. Uma história da eugenia no Brasil e no mundo. São Paulo: Contexto, 2007, p. 21-85.

${ }^{68}$ DIWAN, P. S. Op. cit., p. 21-46.

${ }^{69}$ Trata-se do discurso de Hubert Markl, presidente da Sociedade Max Planck, quando do lançamento do programa de pesquisa História da Sociedade Kaiser Wilhelm na Era Nacional Socialista, em 1999, para investigar o envolvimento da SKW nos crimes nazistas. WEIGMANN, Katrin, op. cit, p. 871.

${ }^{70}$ Idem, p. 874.

${ }^{71}$ MÜLLER-HILL, B. Op. cit., p. 19.

${ }^{72}$ Idem, p. 92.

${ }^{73}$ Idem, p. 80.

${ }^{74}$ Cf. LANZMANN, Claude. Shoah. Vozes e faces do holocausto. São Paulo: Brasiliense, 1987; SZPILMAN, Wladislaw. $O$ pianista. Rio de Janeiro: Record, 2003.

${ }^{75}$ BLACK, E. Op. cit., p. 401, 131, 93, 20.

${ }^{76}$ MÜLLER-HILL, B. Op. cit., p. 97-98.

772 Reis, 17, 15-18.

${ }^{78}$ ARISTÓTELES, Poética, XXII, 144, 1459a 5-10.

${ }^{79}$ MÜLLER-HILL, B. Op. cit., p. 103.

${ }^{80}$ BAUMAN, Z. Op. cit., p. 15-16.

${ }^{81}$ Idem, p. 31.

${ }^{82}$ Idem, p. 120.

${ }^{83}$ Idem, p. 134.

${ }^{84}$ Idem, p. 32.

${ }^{85}$ Trata-se da oitava tese de "Sobre o conceito de história”: "A tradição dos oprimidos nos ensina que o 'estado de exceção' em que vivemos é na verdade a regra geral. Precisamos construir um conceito de história que corresponda a essa verdade. Nesse momento, perceberemos que nossa tarefa é originar um verdadeiro estado de exceção; com isso, nossa posição ficará mais forte na luta contra o fascismo. Este se beneficia da circunstância de que seus adversários o enfrentam em nome do progresso, considerado como norma histórica. O assombro com o fato de que os episódios em que vivemos no século XX 'ainda sejam possíveis', não é um assombro filosófico. Ele não gera nenhum conhecimento, a não ser o conhecimento de que a concepção de história da qual emana semelhante assombro é insustentável.” BENJAMIN, Walter. Obras escolhidas. Magia e técnica, arte e política. 2 ed. São Paulo: Brasiliense, 1986. p. 226.

${ }^{86}$ CASTORIADIS, C. Op. cit., p. 307.

${ }^{87}$ BAUMAN, Z. Op. cit., p. 107.

\section{Referências e fontes}

ARENDT, Hannah. Entre o passado e o futuro. 5ae ed. São Paulo: Perspectiva, 2000. . A vida do espírito. O pensar. O querer. O julgar. Rio de Janeiro: Relume Dumará, 1992.

ARISTÓTELES. Poética. Tradução de Eudoro de Souza. São Paulo: Ars Poetica, 1992. Retorica. Edição, tradução, prólogo e notas de Antonio Tovar. Madrid: Centro de Estudios Constitucionales, 1990. 
BAUMAN, Zygmunt. Modernidade e holocausto. Rio de Janeiro: Zahar, 1998 [1996].

BERCÉ, Yves-Marie. O rei oculto: salvadores e impostores. Mitos políticos populares na Europa moderna. Bauru: EDUSC; São Paulo: Imprensa Oficial do Estado, 2003.

BENJAMIN, Walter. Obras escolhidas. Magia e técnica, arte e politica. 2ª ed. São Paulo: Brasiliense, 1986. A Bíblia de Jerusalém. São Paulo: Paulinas, 1985.

BLACK, Edwin. A guerra contra os fracos: a eugenia e a campanha dos Estados Unidos para criar uma raça dominante. São Paulo: A Girafa, 2003.

BRISSON, Luc. Leituras de Platão. Porto Alegre: EDIPUCRS, 2003 [2000].

CALAME, Claude. Mythe et histoire dans l'Antiquité Grecque. La création symbolique d'une colonie. Lausanne: Payot, 1996.

. The rhetoric of mythos and logos: forms of figurative discourse. In: BUXTON, Richard (ed.). From myth to reason? Studies in the development of greek thought. Oxford: Oxford UP, 1999. p. 140-141.

CASSIN, Barbara. O efeito sofistico. São Paulo: 34, 2005 [1995].

CASTORIADIS, Cornelius. A pólis grega e a criação da democracia. In: Os domínios do homem. Rio de Janeiro: Paz e Terra, 1987 [1986].

CASTRO, Eduardo Viveiros de. A inconstância da alma selvagem. São Paulo: Cosac \& Naify, 2002.

CICERO, Marco Túlio. Dos deveres. São Paulo: Martins Fontes, 1999.

CORNFORD, Francis Macdonald. Principium sapientiae. As origens do pensamento filosófico grego. Lisboa: Fundação Calouste Gulbenkian, 1989 [1952].

. Thucydides Mythistoricus. Philadelphia: University of Pennsylvania, 1971 [1907].

CRANE, Gregory. The blinded eye. Thucydides and the new written word. Boston: Rowmann \& Littlefield, 1996.

DAMÁSIO, Antônio R. O erro de Descartes. Emoção, razão e o cérebro humano. São Paulo: Companhia das Letras, 1996 [1994].

DETIENNE, Marcel. A escrita de Orfeu. Rio de Janeiro: Jorge Zahar, 1991 [1989].

. A invenção da mitologia. Rio de Janeiro: Jorge Zahar, 1992 [1982].

DIWAN, Pietra Stefânia. Raça pura. Uma história da eugenia no Brasil e no mundo. São Paulo: Contexto, 2007.

FILIPOVIC, Zlata; CHALLENGER, Melanie (Orgs.). Vozes roubadas. Diários de guerra. São Paulo: Companhia das Letras, 2008 [2006].

GEERTZ, Clifford. A interpretação das culturas. Rio de Janeiro: Zahar, 1978 [1973].

GINZBURG, Carlo. Olhos de madeira. Nove reflexōes sobre a distância. São Paulo: Companhia das Letras, 2001 [1998].

. Relaçôes de força. São Paulo: Companhia das Letras, 2002 [2000].

GOODY, Jack. Domesticação do pensamento selvagem. Lisboa: Editorial Presença, 1988 [1977].

GUERREIRO, Mario A. Repensando o conceito platônico de dianoia. Revista Princípios. Departamento de Filosofia/UFRN, Natal, v. II, n. 1, junho 1995. p. 126-134. Disponível em <http://dialnet.unirioja.es/servlet/ articulo?codigo=2565595>. Acesso em: 28 fev 2009.

HOBSBAWM, Eric. Dentro e fora da história. In: Sobre História. São Paulo, Companhia das Letras, 1998 [1997].

. Naçôes e nacionalismo. Programa, mito e realidade. Rio de Janeiro: Paz e Terra, 1991 [1990].

HOMERO. Ilíada. 4 ed. Tradução de Haroldo de Campos. Introdução e organização de Trajano Vieira. São Paulo: ARX, 2003 [2001].

LANZMANN, Claude. Shoah. Vozes e faces do holocausto. São Paulo: Brasiliense, 1987 [1985]

LÉVI-STRAUSS, Claude. O pensamento selvagem. Campinas: São Paulo, 1989 [1962].

LLOYD, Geoffrey. Mythology: reflections from a chinese perspective. In: BUXTON, Richard (Ed.). From myth to reason? Studies in the development of greek thought. Oxford: Oxford UP, 1999. p. 164-165.

MCKIRAHAN JR., Richard D. Philosophy before Socrates: an introduction with texts and commentary. Cambridge: Hacket, 1994. 
MEIER, Michel. Prefácio. In: ARISTÓTELES. Retórica das paixōes. Introdução, notas e tradução do grego de Isis Borges B. da Fonseca. São Paulo: Martins Fontes, 2000.

MÜLLER-HILL, Benno. Ciência assassina. Rio de Janeiro: Xenon, 1993 [1984].

NIETZSCHE, Friederich. Crepuisculo dos ídolos ou como se filosofa com o martelo. São Paulo: Companhia das Letras, 2006.

NAGY, Gregory. The best of the achaeans. Concepts of the hero in archaic Greek poetry. Baltimore: The Johns Hopkins University, 1979.

OUDEMANS, Th C. W. \& LARDINOIS, A. P. M. H. Tragic Ambiguity. Anthropology, Philosophy and Sophocles' Antigone. Leiden: Brill, 1987.

PALLARES-BURKE, Maria Lúcia Garcia. Entrevista com Zygmunt Bauman. Tempo Social, São Paulo, v.16, n.1, Junho 2004. Disponível em: <http://www.scielo.br/scielo.php?script=sci_arttext\&pid=S0103$20702004000100015 \& \operatorname{lng}=e n \& n r m=i s o>$. Acesso em: 18 fev 2009.

PARMÊNIDES. Da natureza. São Paulo: Loyola, 2002. Tradução de José Trindade Santos.

PLATÃO. Diálogos. Teeteto. Crátilo. 3 ed. Tradução de Carlos Alberto Nunes. Belém: UFPA, 2001 [1973].

. Fedro ou da beleza. Tradução e notas de Pinharanda Gomes. Lisboa: Guimarães, 2000.

PLATO. Letters. In: CRANE, Gregory. The Perseus Project. Disponível em: <http://www.perseus.tufts.edu>. Acesso em: 20 mar 2008.

PEREIRA, Oswaldo Porchat. Vida comum e ceticismo. São Paulo: Brasiliense, 1994 [1993].

SANTORO, Fernando. O poema de Parmênides. 2006. 1 CD-ROM.

SERRA, Ordep. A antropologia, a mitologia e sua escrita. Clássica. São Paulo, v. 11/12, p. 15-36. 1998/1999.

SÓFOCLES. Antígona. 6 ed. Tradução de Maria Helena da Rocha Pereira. Lisboa: Calouste Gulbenkian, 2003 [1997].

Antigone. In: CRANE, Gregory. The Perseus Project. Disponível em: <http://www.perseus.tufts.edu>. Acesso em: 30 jul 2009.

SZPILMAN, Wladislaw. O pianista. Rio de Janeiro: Record, 2003 [1998].

VARGAS, Eduardo Vianna. Gabriel Tarde e a diferença infinitesimal. In: dologia e outros ensaios. São Paulo: Cosac \& Naify, 2007. (Org.). Gabriel Tarde. A mona-

VERNANT, Jean-Pierre. Como um barco à deriva. Três colegas do Collège de France. Teoria \& pesquisa: Revista de Ciências Sociais, São Carlos, v. XVI, p. 173-188, n. 2, jul./dez. 2007. Entrevista concedida a José Otávio Nogueira Guimarães. Disponível em: <http://www.teoriaepesquisa.ufscar.br/index.php/tp/article/ viewFile/113/90>. Acesso em: 30 abr 2009.

. Entre mito e politica. São Paulo: EDUSP, 2001 [1996].

. A formação do pensamento positivo na Grécia Arcaica. In: . Mito e pensamento entre os gregos. Rio de Janeiro: Paz e Terra, 1990.

Fronteiras do mito [1996]. In: FUNARI, Pedro Paulo (Org.). Repensando o Mundo Antigo. Campinas: UNICAMP, 2005. Série textos didáticos, n. 47, fev. 2005.

[1974].

. Razones del mito. In: . Mito y sociedad en la Grecia antigua. 2.ed. Madrid: Siglo Veintiuno, 1987

VEYNE, Paul. Acreditavam os gregos em seus mitos? São Paulo: Brasiliense, 1984 [1983].

. Foucault révolutione l'histoire. In: Comment on écrit l'histoire. Paris: Seuil, 1971.

. Como se escreve a história. Lisboa: Edições 70, 1981.

. Como se escreve a história. Brasilia: UnB, 1982.

WEIGMANN, Katrin. In the name of science. European Molecular Biology Organization (EMBO) Reports. Heildelberg: EMBO, 2001. Disponível em <http://www.pubmedcentral.nih.gov/articlerender.fcgi?tool=pubme $\mathrm{d}$ \&pubmedid $=11600445>$. Acesso em: 8 jan 2009.

WILDE, Oscar. The Rise of historical criticism. Disponível no CELT: The Corpus of Electronic Texts: <http:// www.ucc.ie/celt/online/E800003-001/>. Acesso em: 24 abr 2009. 
RAZÃo, CEgueira E MiTo

Anderson Zalewski Vargas

\title{
RESUMO
}

Este artigo trata da incapacidade de a razão - genericamente concebida como a inteligência e o saber associados à ciência, à história, ao conhecimento sistemático - reconhecer-se como responsável por atos abomináveis, como se fosse sobrehumana. Aborda um provável motivo dessa apreciação - a ilusão de rompimento necessário e inevitável com o mundo sensivel para a elaboração de um saber verdadeiro - e avalia a importância das noções de mito e mitologia para a sustentação dessa cegueira peculiar do saber racional, a partir da crítica de certas avaliaçôes históricas da eugenia e do Holocausto.

Palavras-chave: racionalidade, retirada do mundo, aparências, cegueira, mito, eugenia, Holocausto.

\begin{abstract}
This article deals with the incapacity of reason - generally thought as intelligence and a knowledge linked to science, history, to a systematic learning - to assumes itself as the perpetrator of abominable acts as it were a suprahuman thing. It approaches a probable motivation of this thought - the illusion of a necessary rupture with the sensible world to elaborate a true knowledge - and estimate through the criticism of some historical analyses of the Eugenics and Holocaust the importance of the notions of myth and mythology as supporters of the peculiar blindness of the reason. Keywords: rationality, withdrawal from the world, appearances, blindness, myth, Eugenics, Holocaust.
\end{abstract}

